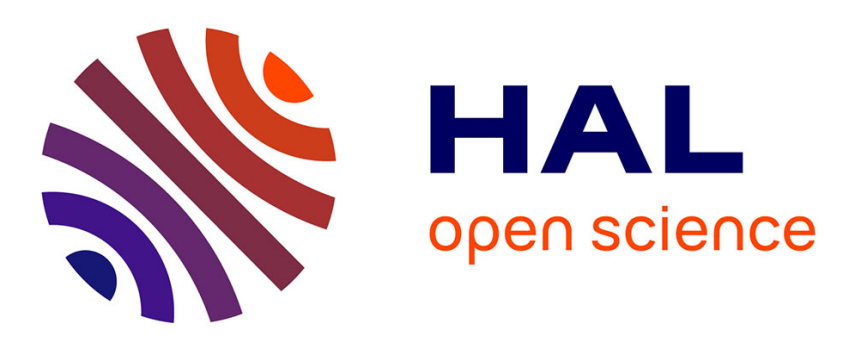

\title{
STUDY OF SURFACES COVERED BY THIN FILMS, BY SPEC AND RAMAN SPECTROSCOPY
}

M. Froelicher, Anne Hugot-Le Goff, V. Jovancicevic, R. Dupeyrat, M. Masson

\section{To cite this version:}

M. Froelicher, Anne Hugot-Le Goff, V. Jovancicevic, R. Dupeyrat, M. Masson. STUDY OF SURFACES COVERED BY THIN FILMS, BY SPEC AND RAMAN SPECTROSCOPY. Journal de Physique Colloques, 1983, 44 (C10), pp.C10-187-C10-190. 10.1051/jphyscol:19831038 . jpa00223495

\section{HAL Id: jpa-00223495 https://hal.science/jpa-00223495}

Submitted on 1 Jan 1983

HAL is a multi-disciplinary open access archive for the deposit and dissemination of scientific research documents, whether they are published or not. The documents may come from teaching and research institutions in France or abroad, or from public or private research centers.
L'archive ouverte pluridisciplinaire HAL, est destinée au dépôt et à la diffusion de documents scientifiques de niveau recherche, publiés ou non, émanant des établissements d'enseignement et de recherche français ou étrangers, des laboratoires publics ou privés. 


\section{STUDY OF SURFACES COVERED BY THIN FILMS, BY SPEC AND RAMAN SPECTROSCOPY}

M. Froelicher, A. Hugot-Le Goff, V. Jovancicevic*, R. Dupeyrat ${ }^{*}$ and M. Masson ${ }^{* *}$

G.R. 4 du C.N.R.S., "Physique des Liquides et Electrochimie", associé à l'Universite lierre et Marie Cumie, Tour 4R, 4, Place Jussien, 75230 Paris Cedex os, France

* Centre de Recherches au Fer-Blanc, B.P. 135, Chaussée d'Europe, 57103 Thionvilie Cedex, France

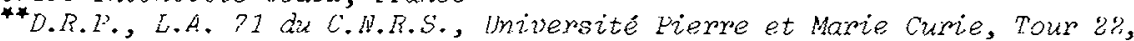
4, Place Jussieu, 75230 Paris Cedex os, France

Résumé - On décrit ici deux techniques originales, adaptées à l'étude et à Tidentification in-situ de films solides fins, apparaissant au cours de traitements électrochimiques : la spectrophotoélectrochimie (SPEC), c'est-à-dire l'analyse spectrale des courants électrochimiques photogénérés dans le film, d'une part, et d'autre part la spectroscopie Raman, utilisée au cours de l'électrolyse. Ces techniques sont appliquées à l'étude de la passivité du fer.

Abstract - Two new techniques, well-suited to the in-situ study and identification of the thin films grown during electrochemical processes are described here: on the one hand the spectrophotoeiectrochemistry (SPEC) i.e., the spectral analysis of the photogenerated electrochemical currents in the film, and, on the other hand, Raman spectroscopy during electrolysis. These techniques are applied to the study of the passivity of iron.

The optical techniques are particularly well-suited to the study of the electrochemical systems, since they can be used in-situ during electrolysis. But, when the system consists of a thin solid film covering a metallic electrode, one encounters a failure of most of the usual techniques : for instance, in the particularly complex case of the passivity of iron, where several axihydroxide or oxide modifications are possible, a knowledge of only the optical indices is insufficient to give a complete chemical identification of the film.

Of course, this chemical identification could be done, without any ambiguity, by Raman spectroscopy, but, with the small amount of material present, one is at the limit of the sensitivity for this technique. Therefore it is useful to have in parallel, spectrophotoelectrochemical measurements (SPEC), giving the shape of the response to the light excitation for a film polarised in an electrolytic solution.

\section{I - EXPERIMENTAL}

Raman spectroscopy. Wie have measured spectra with DILOR RT 30 spectrometer with an interface specialiy designed for an APPLE 2 computer, which allows the accumulation of spectra and the substraction of background. This capability seemed to us useful for substracting the spectrum of the electrolytic solution. The sample was placed flat in the electrolyse cell, it received illumination at grazing incidence by a laser beam ; the Raman light collected at right angle entered the spectrometer by a microscope, passing through one mm solution. The output of laser power is generally $400 \mathrm{mhi}$, and we use $4880 \AA$ radiation, the results being the same with the $5145 \AA$. 
We observed no noticeable change in the spectra between TE or TM modes of propagation. The spectral range available for the study of iron oxides was between 200 and $750 \mathrm{~cm}^{-1}$.

SPEC . When a semiconducting material is illuminated with a light energy higher than the edge of its optical absorption, and when it is polarized by an electrolyte, one observes a sharp increase of the current, $i_{T a}$, followed by a decrease, ita, and a stabilisation to a steady-state value, $i_{s s a}$, which is different from the vajue of the dc electrolyse current. When the sample is darkened, one observes another transient current, $i_{t c}$, having an opposite sign and a value comparable to the value of $i_{t a}$. One can say, to a first approximation, that $i_{T a}$ gives a picture of all the sites where an e-h pair can be created, i.e. it represents the optical absorption in the semiconducing material, coriing from a charge transfer phenomenon; the currents ita and itc give a picture of the sites where the trapping of one of the carriers can occur. The spectral distribution of these different currents, and the time constants of the transients, can give valuable information about the material, and can lead to its identification.

However, these photocurrents are generally weak, over all in the present case (thin film) where the amount of material is low. To overcome this difficulty, we have built a special differential amplifier which allows to separate the photocurrent having an amplitude of about $0.5 \mathrm{nA}$ from the very much larger dc currents. Under these conditions, and the jllumination of a $450 \mathrm{~W}$ Xenon lamp, we are able to follow the passivity of iron overall its range, and to work with films having thickness between a monolayer and $50 \AA$.

Electrochemistry. The iron samples were polarized in different electrolytes, and for instance in the sulfuric acid solution, the passive range extends from 0 io $1 \mathrm{~V} / \mathrm{SSE}$ (reference electrode at saturated sulfate).

Standards. These two methods required standards : we have used single crystals of hemátite, $\alpha-\mathrm{Fe}_{2} \mathrm{O}_{3}$, and magnetite, $\mathrm{Fe}_{3} \mathrm{O}_{4}$. Unfortunately, we had no $\alpha-\mathrm{FeOOH}$, which is supposed to piay an important role in the passivation processes. We have also studied the thermaliy grown oxides on iron to compare the results of the two techniques : when the oxidation temperature is above $400^{\circ} \mathrm{C}$, one obtains the hematite, and when it is below $200^{\circ} \mathrm{C}$ one obtains the magnetite. A range of temperature exists where one produces mixture of these two modifications $/ 1 \%$. These spectrum allows us to explain results found for the case of passive films. For Raman and for SPEC, the reference samples were polarized under the same conditions as the passive iron.

\section{II - RESULTS}

\section{Raman Spectroscopy}

1. Role of the solution. Figure 1 gives the in-situ Raman spectrum (the sum of 4 scans) of a fim having thickness of about 150-200 A. The technique for increasing the thickness of a film has been shown by Arvia and Pallotta (unpublished results), and involved the use of many very fast oxidation-reduction cycles (O.R.C.). The thickness of films is estimated form the interference in the optical spectrum of oxidized iron. The presence of $\mathrm{Fe}_{3} \mathrm{O}_{4}$ is clearly seen in the figure 1 with the two peaks at $550 \mathrm{~cm}^{-1}$ and $676 \mathrm{~cm}^{-1} / 1,2 /$. The presence of electrolyte prevents any observation below $350 \mathrm{~cm}^{-1}$; but after this value, the $\mathrm{KOH}$ solution, as the most of passivating solutions, reproduces the water spectrum; its faint broad maximum at 450 $\mathrm{cm}^{-1}$ is even not detectable here. On the contrary, the study in-situ of the passivation in sulfuric acid solution is impossible because of the number and magnitude of the Raman peaks in the range.

2. Identification of a passive film . Figure 2 gives the Raman spectrum of a film grown potentiostat obtained after removing sample out of the electrolyte. This sample has been polarized exactly under the passivation conditions but its thickness was thicker than the "actual" passive film by maintaining the polarization for 60 hours : it has reach a 
thickness comparable to these of the precedent sample (figure 1). Here, the two first peaks at $300 \mathrm{~cm}^{-1}$ and $412 \mathrm{~cm}^{-1} / 3 /$ are characteristic of $\mathrm{Fe}_{2} \mathrm{O}_{3}$ and one also sees the two peaks from $\mathrm{Fe}_{3} \mathrm{O}_{4}$ : therefore one has a mixture of magnetite and hematite. This spectrum has some points in common with the spectrum of $\alpha-F e O O H$ published in the literature /4/ but the main difference is in the position of the main peak, which is at $385 \mathrm{~cm}^{-1}$ in the oxihydroxide, and at $413 \mathrm{~cm}^{-1}$ either in pure hematite, or as seen on the thermal oxides, in samples mixed with magnetite. This preliminary study allows us then to ascertain that one has the mixture of oxides, and not the oxinydroxide.

The Raman spectroscopy has now proved for the first time that magnetite is always present, in films grown under conditions near that of the passivation. This is of great significancc, because the majority of the theories used in electrochemistry, assign the passivation phenomenon to the crystallization of purely trivalent species.

SPEC . Figure 3 gives the photocurrent behaviour of a $\mathrm{Fe}_{2} \mathrm{O}_{3}$ single crystal. It reproduces the optical spectrum of hematite, except for the transitions below $3 \mathrm{eV}$ which are crystal-field and ligand transitions. 15/. In this case, steady-state and transients currents give exactly the same spectral distribution. The response of a single crystal of magnetite is quite different $/ 6 /$. The currents $i_{T_{a}}, i_{t a}$ and $i_{\text {tc }}$ have the same spectral distribution, but a steady-state current begins at $3.65 \mathrm{ev}$, which is the absorption edge of $\mathrm{Fe} 0$. This steady-state current is assigned to the presence of $\mathrm{Fe}^{2+}$ ions. This behavior is seen on the figure 4 , which is relative to a passive film, obtained at $0.4 \mathrm{~V} / \mathrm{SSE}$ in a buffer borate solution. A more detailed analys is of the SPEC in single crystals and passive films is done in ref. 6 . The important point here is the identification of $\mathrm{Fe}_{3} \mathrm{O}_{4}$.

In the first part of passive range the currents $i_{\text {ta }}$ and $i_{t c}$ disappear, and one has only a steady state current with the " $\mathrm{Fe}^{2+1}$ structure. One assumes that one has prodably a poorly-crystallized oxide, with $\mathrm{Fe}^{2+}-\mathrm{OH}$ bindings.

\section{III - CONCLUSIONS}

These two approaches have led us point out the presence of divalent iron in the film. The SPEC is an indirect method, which requires a preliminary measurement of standards, and a certain knowledge of the $e-h$ creation and recombination mechanisms in the material. It does not allow us to discriminate between the two modifications having the same $\mathrm{Fe}-\mathrm{O}$ bindings. Its main advantage is to give a response independent of the crystallinity of the compound, and for thin film as monolayers.

The Raman spectroscopy, even by summing the spectra for 10 scans has not given a response for our passive film eventhough their thickenessmay be only 5 times less than the films shown figures 1 and 2. Maybe, the effect of ageing of the sample shown figure 2 is also caused by a higher degree of crystallinity. One has probably a "sandwich" layer, the effect of ageing being to slawly reoxidise the inner layer of $\mathrm{Fe}_{3} \mathrm{O}_{4}$, but also to recrystallize the $\mathrm{film}$. One can then considered that these two techniques have an excellent complementarity.

\section{REFERENCES}

11/ DUPEYRAT R, FROELICHER M., HUGOT-LE GOFF A., JOVANCICEVIC V., MASSON M., "Raman Spectroscopy", Lascombe and Huong Eds. J. Wiley, (1982) 679.

FROELICHER M., HUGOT-LE GOFF A., Le Vide, Les couches minces, 38 (1983), 159.

12/ HART T., TEMKIN H., ADAMS S., "Light Scattering in Solids", Balkansky Ed. (1978), 254.

13/ HART T., ADAMS S., TEMKIN H., "Light Scattering in Soljds", Balkansky Ed. (1978), 259.

14/ KEISER J., BROWN C., HEIDERSBACH R., J. Electrochem. Soc. 122 (1982), 2686. 
15/ MARUSAK L., MESSIER R., WHITE W., J. Phys. Chem. Solids, 41 (1980), 981.

16/ FROELICHER M., HUGOT-LE GOFF A., JOVANCICEVIC V., "Passivity of metals and semiconductors", Froment Ed., Elsevier (1983).

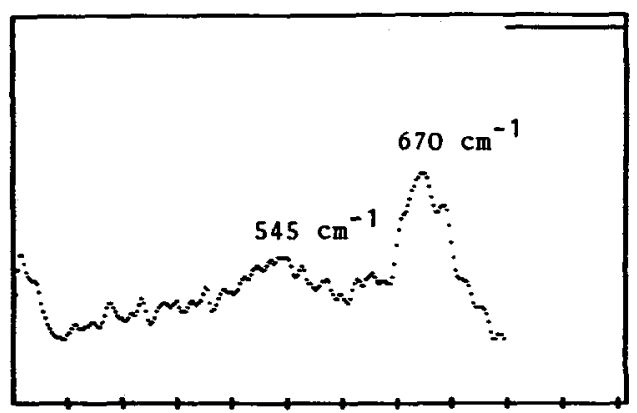

300

Fig. 1. In-situ Raman spectrum of a $200 \AA$ - thick oxide film grown in $1 \mathrm{M} \mathrm{KOH}$ after many $\mathrm{ORC}$.

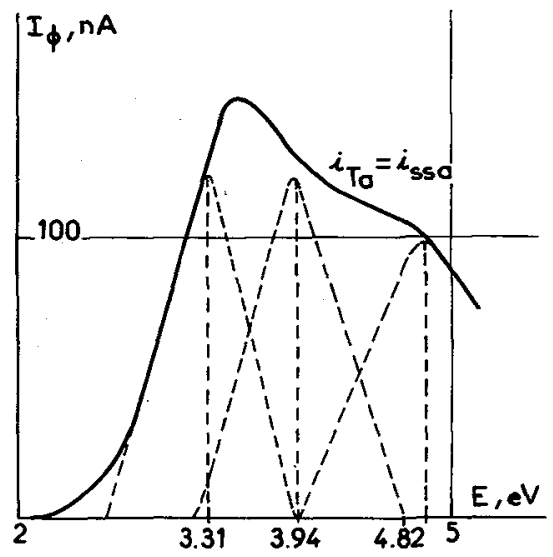

Fig. 3. SPEC spectrum of an hematite single crystal polarized at $0.7 \mathrm{~V} / \mathrm{SSE}$ in buffer borate solution.

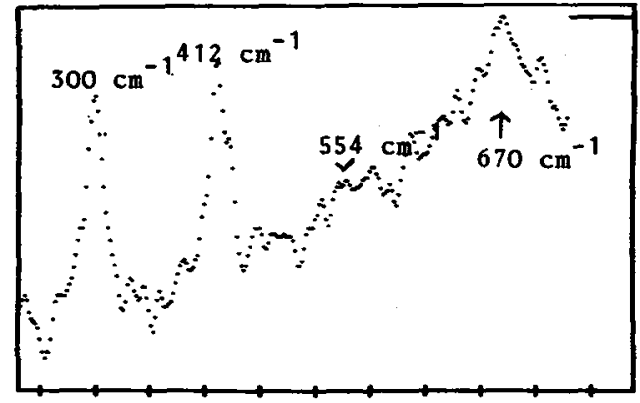

$8 \quad 230$

Fig. 2. Raman spectrum of a $200 \AA$ thick passive film after potentiostatic polarization at $0.6 \mathrm{~V} / \mathrm{SSE}$ in $1 \mathrm{M} \mathrm{H}_{2} \mathrm{SO}_{4}$ during $60 \mathrm{~h}$.

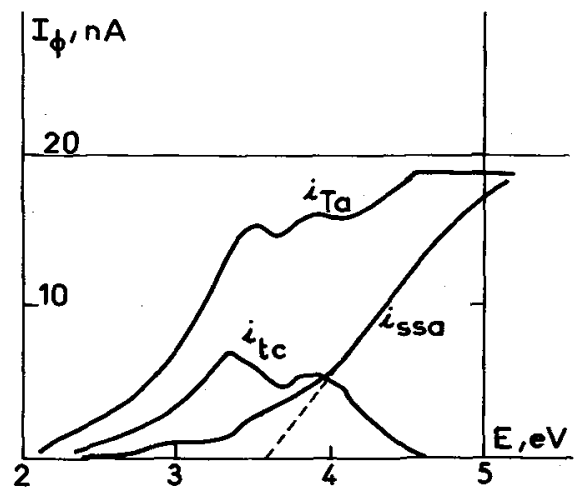

Fig. 4. SPEC spectrum of a passive film polarized at $0.4 \mathrm{~V} / \mathrm{SSE}$ in buffer borate solution. 